\title{
STUDY ON GRAIN STORAGE FACILITIES AS FOOD SECURITY MEASURE IN FLOOD PRONE AREAS OF BANGLADESH
}

\author{
M. S. Alam1, M. A. Ashraf, M. I. A. Mia ${ }^{2}$ and M. Z. Abedin \\ Department of Farm Structure, Bangladesh Agricultural University \\ Mymensingh-2202, Bangladesh
}

\begin{abstract}
The present study aimed at obtaining the existing grain storage facilities their problems and prospects at farmers, commercial, common and cooperative levels on some selected flood prone areas of Bangladesh. The study was conducted at Belkuchi upazila under Sirajgonj district. A total of randomly selected forty farmers and ten traders were surveyed from four villages under four different unions through structured questionnaire. Farmers and traders were classified as small, medium and large on the basis of their total land ownership and annual income status. The farmers used traditional storage structures such as Dole, berh, Motka, Jala, steel drum, gunny and plastic bags and Gola. On the other hand, the traders used gunny and plastic bags and privately owned godowns for storing food grains for short time basis. Average production, consumption, sale, farm use, labour wage, storage volume, cost, durability and losses of different storage structures for major grain crops like paddy, wheat and mustard were identified by farmers and traders category. Considering the capital cost, expected life and storage loss steel drum, gunny and plastic bags and Motka/Jala were found more economical for the farmers. The advantages and disadvantages of farmers, commercial, common and co-operative level storage structures were also identified. As the study area was a flood prone one, average $60 \%$ farmers were affected and average $8 \%$ stored grains were damaged by the flood of 2007 . A total of $73 \%$ farmers and traders expressed their interest on co-operative storage system at the time of flood to store food grains with paying cost as they have no alternative storage facilities other than the proposed safely constructed co-operative storage structures. On the basis of the opinion of farmers and traders, the suitable location and type of storage structure were also proposed. A layout design and the cost of an operational storage structure for storing 60 metric tonnes of paddy and the possible management of the co-operative storage system were also proposed.
\end{abstract}

Key Words : Storage facilities, Food security, Flood prone area, Co-operative storage system

${ }^{1}$ Ministry of Establishment, Government of the People's Republic of Bangladesh, Dhaka ${ }^{2}$ Department of Co-operative and Marketing, Bangladesh Agricultural University, Mymensingh, Bangladesh 


\section{INTRODUCTION}

Bangladesh is an agricultural country where rice is produced as staple food, other cereal crops like wheat, maize, mustard and different type of pulses are also produced in this country. About 89.55 percent of agricultural land or 74.06 percent of total land is used for paddy cultivation (Anon, 1993). The total area and production of rice in Bangladesh is about 11.03 hectares and 26.80 million metric tons respectively (BBS, 2004).

Rice and other cereal crops are produced in all the seasons but the whole volume is not consumed immediately after production. In order to ensure the uniform consumption round the year prompted the need for storage of produced rice. Rice generally stored by the farmers to meet their own consumption, facing emergency needs and seeds for the next sowing season. Storage practices of rice are primitive, traditional and labour intensive varying according to the localities depending on existing physical, topographical and climatic condition of the area. Emphasis has always been given on increasing rice production but not reducing post harvest losses. Annual loss of paddy during storage in Bangladesh is estimated to be 8 to 10 percents (Farouk, 1975). Samajpati et al. (1981) stated that all the process like harvesting, threshing, parboiling, drying and storing are very primitive and time consuming. The post harvest loss of paddy in Bangladesh was as high as 22 percent due to various causes. Those losses could be reduced by improved threshing, drying and storage facilities at farm level.

Grain storage practices in Bangladesh can be divided into three categories; storage by farmers individually, storage by small commercial farms and storage by government and large commercial godowns. In most of the areas of Bangladesh the farmers and remote areas living people store food grains in most of their house hold traditional storage structures like Dole, berh Gola, kuthi, gunny bags, metal drum and plastic drum etc. These structures are not so durable and poor in providing optimum storage conditions. The grains stored in these structures are susceptible to damage by natural calamities like heavy rainfall, flood, cyclone and attack of microorganisms, insects and rodents which cause a considerable damage and loss in every year. Among all the post harvest losses storage loss is playing a vital role. Therefore, it is the burning issue to improve the storage system for the remote areas and poor communities especially in the flood prone areas of Bangladesh. At the time of flood stored food grains are damaged to certain extent and the people have to leave their houses. Storage systems for those particular flood prone areas are of utmost important. Mia and Haq (1994) carried out a study on storage of food grains in the selected flood prone and flood free areas of Bangladesh. They used data collected from Kazipur and Raigonj upazillas under Sirajgonj district and Trisahal upazila under Mymensingh district. Storage losses were only $2.47 \%$ for flood prone areas and $2.63 \%$ for flood free areas. Bringing storage system under a single social system was suggested to get steady supply and benefit to increased rice price.

Commercial farms store food grains in godown. They usually keep grains in gunny and plastic bags and then stack the bags inside godown. The traders buy seasonal grains from the market when price is low and then store these grains for about 4-6 months. When 
price is comparatively high then they sell them in the market. In this method optimum temperature and safe storage moisture content are not strictly maintained. As a result the storage loss at commercial level is high. Government involve in storage for the purpose of stabilizing prices and revenues to the farmers and ensuring national food security.

In Bangladesh co-operative or common storage facilities are virtually absent over t6he years. But in the flood and cyclone prone areas of the country safely constructed cooperative storage structures are essential to provide large advantages for the farmers and traders to store grains in the storage structures at the time of sudden natural disaster when the producers or traders find no place for storing their grains.

Food security is a burning issue in this country. A large fraction of the country's population suffers from chronic food insecurity which is related to poverty, natural disaster, manmade calamities and disaster, lower agricultural production and unemployment of a group of people due to seasonality. It was assumed that adequate production would assure adequate availability of food in the market as well as in the house holds. Several studies reveal that sufficient production alone cannot ensure food security as there are insufficient and improper storage facilities at the farmers, private and government levels as well as constraints to access seasonally produced food grains to government storage. Keeping eye on the above crucial points, the objectives of the study to be attended in the present study are as follows:

(a) To identify the existing grain storage facilities in the selected remote and flood prone area of Belkuchi upazila.

(b) To study the problems and prospects of grain storage at farmers, commercial, common and co-operative levels.

(c) To suggest need-based storage systems for the remote and flood prone area of Bangladesh.

\section{MATERIALS AND METHODS}

\section{Field survey}

In order to achieve the goal of the study, primary data were collected through farm survey with the help of pre-tested questionnaire. Two types of questionnaire were used for collecting the data. One was applicable for the farmers and the other was for the traders who are very much related to grain storage. Data were collected for the period from October to November 2007.

\section{Selection of the study area}

Keeping in view the objectives of the present study especially for covering flood prone and remote area four villages namely Aguria, Khidrachapri, Mulkandi and Adachaki of Rajapur, Baradhul, Belkuchi sadar and Bhangabari unions respectively of Belkuchi upazilla under Sirajgonj district were selected as study area. The study areas were also selected on the basis of communication, farmers' altitude to co-operation and availability of almost all storage structures used for storage of food grains by the farmers. 
On the basis of landownership, the farmers were classified into three categories like small farmers having land up to 1.00 hectare; medium farmers having land with 1.01 to 3.00 hectares and large farmers having land exceeding 3.00 hectares. The analysis of data has been done on the basis of land ownership i.e. farm category plays an important role to store crops in different storage structures. The traders related to grain storage are also classified in to three categories on the basis of their income status. These are: (i) small traders having yearly income up to Tk.100,000 (ii) medium traders having yearly income Tk.100,001 to160,000 and (iii) large traders having yearly income exceeding Tk.160,000.

\section{Data acquisition systems}

For collecting data personal visits were made to the house of sampled farmers and the trade centers. At the beginning of the interview, the aims and objectives of the study were explained to each farmer and trader. Then the questions were asked in a very simple manner with explanation of questions where necessary and the replies were recorded in the questionnaire.

In achieving the objectives of the study the collected data were classified, tabulated and analyzed. Lists of tables were prepared in accordance with the aim and objectives of the study. Simple statistical techniques were mainly followed in analyzing the data.

\section{RESULTS AND DISCUSSION}

\section{Production, consumption and storage of paddy}

Table 1 gives the average production, consumption and storage of paddy by farm category and it also reveals that average net production and storage of paddy increased with farm size and average consumption were almost same.

Table 1. Production, consumption and storage of paddy by farm size in the study area

\begin{tabular}{c|c|c|c}
\hline Farm category & $\begin{array}{c}\text { Average net production } \\
(\mathrm{kg})\end{array}$ & $\begin{array}{c}\text { Average consumption for family } \\
(\mathrm{kg})\end{array}$ & $\begin{array}{c}\text { Average storage } \\
(\mathrm{kg})\end{array}$ \\
\hline Small farm & 4449.0 & 2636.0 & 1764.8 \\
Medium farm & 8487.5 & 2617.3 & 2792.7 \\
Large farm & 27369.5 & 2866.7 & 3788.7 \\
\hline
\end{tabular}

\section{Existing grain storage structure}

Farmers of the study area used traditional grain storage structure like Dole, Motka, Jala, steel drum, gunny bag, berh and Gola etc. Traders of the study areas used gunny bag and kept within godown as grain storage structure.

\section{Storage cost and loss of paddy in different storage structure}

Storage cost and storage loss vary in different storage structures depending upon the types of grains to be stored, maintenance of storage quality, storage duration etc. Table 2 reveals that for duration of storage for 5-6 months in study area, the cost of paddy 
storage in Dole is Tk. 4.50 per $40 \mathrm{~kg}$ which is minimum against the maximum storage loss of $3.75 \%$. The storage cost in steel drum is Tk. 10.00 per $40 \mathrm{~kg}$ with the minimum $1.02 \%$ storage loss. Considering the capital cost, expected life, storage loss steel drum, gunny bag and Motka/Jala were found more economical for farmers

Table 2. Storage cost and loss of paddy in different storage structures

\begin{tabular}{l|c|c|c|c|c}
\hline Farm category & Capacity (kg) & $\begin{array}{c}\text { Capital cost } \\
(\mathrm{Tk})\end{array}$ & $\begin{array}{c}\text { Expected life } \\
\text { (year) }\end{array}$ & $\begin{array}{c}\text { Cost per 40 kg } \\
(\mathrm{Tk})\end{array}$ & Loss (\%) \\
\hline Dole & 560 & 650 & 3 & 4.50 & 3.75 \\
Motka & 112 & 400 & 4 & 12.00 & 1.50 \\
Sleel drum & 224 & 800 & 10 & 10.00 & 1.02 \\
Gunny bag & 75 & 50 & 3 & 10.00 & 1.25 \\
Berh & 1300 & 1500 & 5 & 6.00 & 3.50 \\
Gola & 4490 & 7000 & 10 & 5.00 & 3.00 \\
\hline
\end{tabular}

\section{Storage cost and loss of wheat in different storage structures}

In the study area production of wheat is very low. Farmers stored wheat in steel drum and gunny bag. Table 3 reveals that loss of storage in steel drum was lower than loss of storage in gunny bag.

Table 3. Storage cost and loss of wheat in different storage structures

\begin{tabular}{c|c|c|c|c|c}
\hline $\begin{array}{c}\text { Storage } \\
\text { structure }\end{array}$ & Capacity (kg) & $\begin{array}{c}\text { Capital cost } \\
(\text { Tk.) }\end{array}$ & $\begin{array}{c}\text { Expected life } \\
\text { (Year) }\end{array}$ & $\begin{array}{c}\text { Cost per 40 kg } \\
(\mathrm{Tk})\end{array}$ & Loss (\%) \\
\hline Steel drum & 224.34 & 800 & 10 & 12 & 1.5 \\
Gunny bag & 74.78 & 50 & 3 & 10 & 2.5 \\
\hline
\end{tabular}

\section{Storage cost and loss of mustard in different storage structures}

In the study area production of mustard was also low but higher than wheat. Farmers stored mustard in gunny bags and Jala. Table 4 reveals that the loss of storage in Jala was lower than that in gunny bags.

Table 4. Storage cost and loss of mustard in different storage structures.

\begin{tabular}{l|c|c|c|c|c}
\hline $\begin{array}{c}\text { Storage } \\
\text { structure }\end{array}$ & Capacity (kg) & $\begin{array}{c}\text { Capital cost } \\
(\mathrm{Tk} .)\end{array}$ & $\begin{array}{c}\text { Expected life } \\
(\text { Year })\end{array}$ & $\begin{array}{c}\text { Cost per 40 kg } \\
(\mathrm{Tk})\end{array}$ & $\begin{array}{c}\text { Rate of loss } \\
(\%)\end{array}$ \\
\hline Jala & 74.78 & 200.00 & 5 & 20.00 & 1.0 \\
Gunny bag & 74.78 & 50.00 & 3 & 12.00 & 1.5 \\
\hline
\end{tabular}

\section{Storage cost and loss of stored grain by traders category}

In the study area selected traders stored only paddy for earning business profit. Table 5 shows the duration of storage, cost and loss of storage by traders category. Table 5 reveals that cost and loss of storage decreased with trader's farm size. 
Table 5. Storage cost and loss of paddy stored in gunny bag kept in godown by traders

\begin{tabular}{l|c|c|c}
\hline \multicolumn{1}{c|}{ Traders category } & $\begin{array}{c}\text { Duration of storage } \\
\text { (month) }\end{array}$ & Cost per $40 \mathrm{~kg}$ (Taka) & Storage loss of (\%) \\
\hline Small & 5 & 16 & 2.20 \\
Medium & 4.5 & 13 & 1.92 \\
Large & 5 & 11 & 1.50 \\
\hline
\end{tabular}

\section{Flood affecting storage of food grains}

The study area was the flood prone ones. Among 6 unions of the selected upazila, 3 unions (Rajpur, Belkuchi Sadar and Baradhul) are the most vulnerable area than other areas of Bangladesh. In every year a large portion of these unions has been suffering from flood damage. Table 6 shows the number of affected farm and damage of stored crops. Table 6 reveals that the percent of farm affected by flood and damaged crop percentage decreased with farm size.

Table 6. Farms affected by flood and damaged of stored grain

\begin{tabular}{l|c|c|c|c}
\hline \multicolumn{1}{c}{ Farm category } & Number of farm & $\begin{array}{c}\text { Number of farm } \\
\text { affected by flood }\end{array}$ & \% of farm & $\begin{array}{c}\text { Damage of stored } \\
\text { crop (\%) }\end{array}$ \\
\hline Small & 11 & 8 & 73 & 10 \\
Medium & 26 & 18 & 69 & 8 \\
Large & 3 & 1 & 34 & 5 \\
\hline
\end{tabular}

\section{Appreciation of common storage and co-operative storage}

As the study area is a flood prone area and flood causes considerable damages in most of the farm almost every year. There were no common or co-operative storage structures erected in the study area. But the respondent of the sample farms and the concerned traders expressed their interest in common or cooperative storage. Because at the time of flood farmers houses and stored grains including structure are damaged to some extent and they have no alternative storage system for storing food grains. So, appreciation of flood free durable and functional common storage as made by the farmer's/trader's own cost and possibility of co-operative storage are examined by farmer's/trader's opinion. Table 7 and Table 8 show the appreciation of common and co-operative storage by farms and trader's category respectively. The tables reveal that most of the farmers and traders were very much interested about co-operative storage and they were committed to store their food grain in co-operative storage by paying the associated costs.

Table 7. Appreciation of common and cooperative storage by farm category.

\begin{tabular}{l|c|c|c|c|c}
\hline $\begin{array}{c}\text { Farm } \\
\text { category }\end{array}$ & $\begin{array}{c}\text { Number } \\
\text { of farm }\end{array}$ & $\begin{array}{c}\text { Interested for common storage } \\
\text { (Privately owned) }\end{array}$ & \% of farm & $\begin{array}{c}\text { Interested for co- } \\
\text { operative storage }\end{array}$ & $\%$ of farm \\
\hline Small & 11 & 2 & 8 & 9 & 82 \\
Medium & 26 & 3 & 12 & 23 & 88 \\
Large & 3 & 1 & 34 & 2 & 66 \\
\hline
\end{tabular}


Table 8. Appreciation of common and cooperative storage by traders category

\begin{tabular}{lccccc}
\hline $\begin{array}{l}\text { Trader's } \\
\text { category }\end{array}$ & $\begin{array}{c}\text { Number of } \\
\text { farm }\end{array}$ & $\begin{array}{c}\text { Interested for common } \\
\text { storage }\end{array}$ & \% of farm & $\begin{array}{c}\text { Interested for co- } \\
\text { operative storage }\end{array}$ & \% of farm \\
\hline Small & 4 & 1 & 25 & 3 & 75 \\
Medium & 4 & 1 & 25 & 3 & 75 \\
Large & 2 & 1 & 50 & 1 & 50 \\
\hline
\end{tabular}

\section{Location and type of co-operative storage structures}

The farmers and traders of the flood prone area expressed their keen interest about cooperative storage structures. Then the opinions of the farmers and traders about the suitable location and type of such storage structure were observed. Most of the farmers suggested that the location of such structure should be at an important place (above flood danger level) in their own ward and the type of structure should be a pucca building. Most of the traders suggested that the location of such structure should be at Hat/Bazar level and the type of storage structure should be a pucca building as well. The sensible reason for selecting these locations is basically no alternative place for storing food grains during flood. The type of structure would be the pucca ones for ensuring the security, durability and storage quality.

\section{Appreciation of training on storage and government help provision}

The farmers and traders of Bangladesh are mostly lacked of knowledge about the importance of good storage and its management. Financial conditions of the farmers are not at all good. They need government help in various forms for production and storage of produced crops especially food grain crops. This type of help is very much deserving in the flood prone areas of the country. During the survey in the study area, farmers and traders expressed their interest on training about storage and government help through some operational grants or micro-credit financing. As the farmers and traders are lacked of knowledge and experience about the maintenance of storage quality and they need training and awareness on safe storage and government help. If the farmers and traders would be trained they could properly and efficiently store their produced grain and ultimately the losses of storage would be reduced to a reasonable extent and thereby the quality of stored grain would be better.

\section{Need-based storage system}

One of the objectives of the study is to identify the need based storage system for ensuring food security in remote and flood prone areas of Bangladesh. The main river side areas of the country are affected more or less in every year by flood. During flood, houses including storage structure of farmers and traders are damaged to certain extent and they fall in a position of food insecurity. In the study area of Belkuchi upazila an average $60 \%$ farms were affected by flood and average $8 \%$ stored grains were damaged in the flood of 2007. Among the sampled farmers and traders $73 \%$ respondent expressed their appreciation about co-operative storage structure to store their grain with paying costs. Because in the flood prone areas flood stays sometimes several weeks and at that 
time there is no alternative storage system other than the safely constructed one under co-operative storage system. Basically, the government storage structures are neither sufficient nor allowed farmers and traders to store their food grains. The farmers released their opinion that the location of these types of structures should be at a safe important location in every ward of a union so that every stakeholders could get on the opportunity of using the storage facilities. The traders opined that the location should be at Hat/ Bazaar level. The communication of that place should be smooth and easily accessible. For ensuring storage security and good maintenance of quality the structure should be a pucca building with storage capacity of minimum 60 metric tones because this capacity is good enough for about 150 farmers to store per head $400 \mathrm{~kg}$ of food grains before the impending disaster. The proposed storage structure could be accommodated within 5 decimal of land.

The layout design details for a proposed ideal bag storage structure for storing 60 Metric Tonnes of paddy are as follows

\section{Size of the storage structure}

The dimension of a gunny bag 100x60×30 $\mathrm{cm}$ has the capacity of storing $75 \mathrm{~kg}$ and hence the number of bags required to store are 770 .

Let there be 5 bags in length and 5 bags in width arranged in a stack;

Number of bags, therefore, required per layer in a stack $=5 \times 5=25$

If their are 12 layers in a stack so that total number of bags per stack becomes $=12 \times 25=$ 300

Hence the number of stacks required $=\frac{770}{300}=2.56=3$ (approx.)

Therefore, the space required by each stack are;

Length $=(5 \times 1.0)=5.0$ meters

Width $=(5 \times 0.6)=3.0$ meters

Height $=(12 \times 0.3)=3.6$ meters

The clear distance between the walls and the end of stack $=0.8$ meters.

The clear distance between two stacks $=2.0$ meters.

Hence the length of floor $=(3 \times 3.0)+(2 \times 2.0)+(2 \times 0.8)=15.6$ meters $=16$ meters.

Width of floor $=(5 \times 1.0)+(2 \times 0.8)=6.6=7$ meters.

So, the overall dimension of the required structure $=16 \times 7$ meter or $53 \times 23 \mathrm{ft}$. and the height of the walls may be kept as 5.0 meter or $16.5 \mathrm{ft}$. above the plinth level the layout of the proposed bag storage is shown in Fig. 1.

\section{Cost of the structure}

Area of the storage structure $=53 \times 23$ feet $=1219$ sq.ft.

Assuming cost Tk.1000 per sq.ft., total cost of storage structure $=1219 \times 1000=$ Tk. $12,19,000$. 


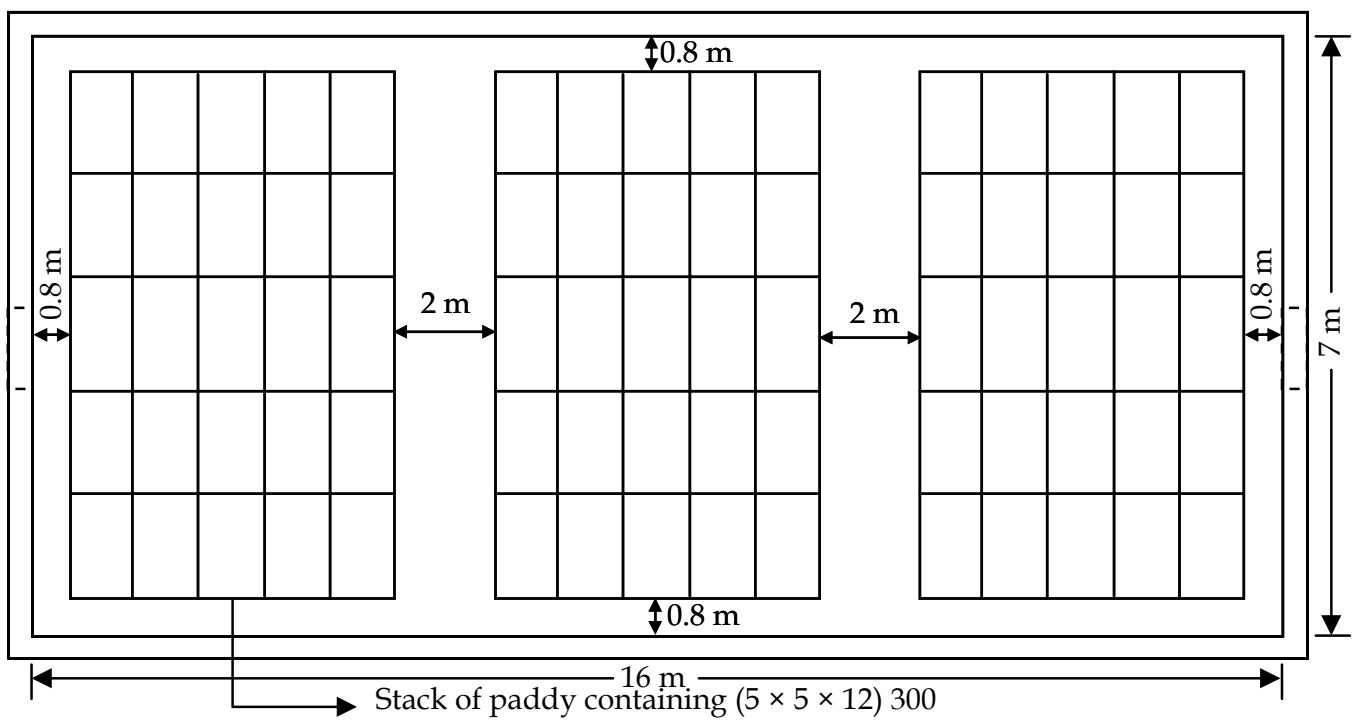

Fig. 1. Typical layout of proposed bag storage structure

\section{Management of co-operative storage}

There would be a managing committee for every co-operative storage structure towards proper management. Before construction of a co-operative storage structure there must be a registered co-operative society in every ward of a union. The members of the cooperative society would select/elect the managing committee. There would be an advisory committee in which UP chairman, concern member, Upazila Agriculture Officer/Food Controller, local elites would be the members of the committee.

- With the help of both advisory and managing committee, government could take imitative towards providing loans and logistic supports in constructing co-operative storage structures.

- Managing committee would take responsibilities in various aspects for better and secured storage system for the storage structures.

- Including Manager of the co-operative storage all member of the managing committee would be trained up on better storage and management system.

- Co-operative society farmer's and trader's of the concern ward have accessibility to storage the amount in the structure as decided by the managing committee.

\section{CONCLUSION AND RECOMMENDATIONS}

The following conclusions and recommendations can be drawn based on the findings of the study:

\section{Conclusion}

1. The farmers of the study area used to store their grain crops (paddy, wheat and mustard) in indoor type traditional storage structures like Dole, berh, steel-drum, 
Motka, Jala, gunny and plastic bags. The tendency of using Dole, Motka, steel drum, berh and gunny bags are higher in small and medium farms which are not so durable and are subjected to storage loss due to various frequently occurred factors like microorganisms, insects, rodents, improper moisture content etc.

2. Traders stored food grains (mainly paddy) in plastic and gunny bags and kept them in the privately owned godowns only $4-5$ months for earning profit. These godowns are well constructed and protected. The storage cost was high but loss was comparatively low.

3. During flood, the house and storage structures and stored grains of farm people are damaged partially or fully. For these reason, there is no alternative other than cooperative storage structure to be constructed in safe and elevated places above flood level.

4. The government has storage systems i.e. LSDs in upazila level. General farmers and traders have no accessibility to use this system. In order to facilitate farmer's and trader's food grain storage, there is no provision for government storage system at the union or village level.

5. Farmers and traders of the study areas have lack of knowledge on storage and they desperately need government help in the form of loans and grants due to insolvent financial condition.

\section{RECOMMENDATIONS}

1. Plinth level of the house of farmers in flood prone areas could be raised above flood level by earth filling. More economical storage structures found in the study areas such as steel drum, gunny and plastic bag, Motka and Jala may be used by the farmers by setting them on an elevated platform made of bamboo or wood.

2. Government storage system should be extended in the union and Hat/Bazar level and farmers and traders could be allowed to store their food grains in the extended storage system.

3. A storage system should be planned with flood cum cyclone shelter in the flood prone and cyclone battered areas so that the people could take shelter with their food grains at the time of impending disaster.

4. Training program on storage of food grains should be developed by the Agriculture Extension Department and the farmers and traders should be trained for better maintenance of storage quality.

5. Government should provide help through loan, grant etc for the development of storage system to farmers and traders since the construction of permanent storage structures has involvement of huge expenditure.

6. There are some storage structures specially the godowns at different growth centers across the country which are now not in use. These structures should be renovated 
and could be transformed to co-operative storage system by proper management practices.

7. Every Union Parishad of Bangladesh has one small Vulnerable Group Development (VGD) godown. The size of these godowns could be increased that would help storage of relief food grains at the time of disaster.

8. In the flood/cyclone prone areas the number of flood cum cyclone shelter including co-operative storage system for food grain should be increased.

9. Community "Paddy Bank", which is recently introduced by an NGO at Nilphamary district, could be established as a model package of storage deal in the flood prone areas of Bangladesh by involving the rural enterprising NGOs.

\section{REFERENCES}

Anonymous, 1993. Bangladesh Arthanaitik Jarip (in Bengali). A report, Ministry of Finance. Government of the People's Republic of Bangladesh.

Ashraf, M.A. 1992. Development of low cost rice storage structure in rural areas of Mymensingh. M. Sc. Thesis, Department of Farm Structure, Bangladesh Agricultural University, Mymensingh

BBS, 2004. Monthly Statistical Buletin. Bangladesh Bureau of Statistics. Ministry of Planning and Development,Dhaka. Bangladesh, October, 2004, p. 57.

Farouk, S. M. 1975. Probable losses in post-harvest operation. How to minimize them. Paper presented at the seminar sponsored by B.A.R.C. Proceedings of the Workshop on Appropriate Agricultural Technology. February 6-8.

Mia, M. I. A. and Haq, A. F. M. F. 1994. Storage of food grains in the selected flood prone and flood free areas of Bangladesh : A farm level study. Journal of The Bangladesh Rural Development Studies.Vol. 4, No. 1\&2.

Samajpati, J. N, Sheikh, M. S. A. and Rahman, M. S. 1981. Paddy post harvest technology in Bangladesh. Agricultural Mechanization in Asia, Africa and Latin America, 12(1) : 39-42. 